\title{
The skewed social image of white South Africans in Nadine Gordimer's The Conservationist
}

\author{
Xiangting Chen ${ }^{1 \varpi}$ \\ ${ }^{1}$ BNU-HKBU United International College \\ 2000 Jintong Road, Tangjiawan, Zhuhai, Gangdong Province, China
}

\begin{abstract}
In this article he examines the social identity crisis of White South Africans in Nadine Gordimer's "The Conservationist". Gordimer describes the psychology, social deformities and human distortions of the repressed white people in post-colonial South Africa. At that time, white South Africans were tortured by colonial guilt and racial contradictions. While recognizing the culture of their European ancestors, they wanted to integrate into the black South African society. This paper analyzes the decline of South African white identity and the phenomenon of white exodus from the perspective of the protagonist's thoughts and behaviors, and combines the political and social problems during those days.
\end{abstract}

\section{Introduction}

Most literature from the apartheid era examines a national identity in crisis, and its reception highlights the issues of South Africa's unique political development. Gordimer's work is set against the background of separation of white and black South African society under the policy of apartheid. It depicts the political situation and turbulent society of South Africa, as well as the revolutionary movement after the awakenings of white and black people. She reveals the serious consequences of apartheid on men, women, children and parents, and shows the confusion of identity felt by the protagonist under the high pressure of South Africa's apartheid policy. The Conservationist was banned in South Africa because of its critique of apartheid. The novel anticipates Bhabha's theoretical term where the "unhomely is the shock of recognition of the world-in-the-home, the home-in-the-world" [1]. The distorted social image maintained by apartheid created an unrealistic sense of national identity for most white South Africans. Where did the white South Africans' national consciousness and exodus come from in the story? Is it as profoundly influenced by apartheid as Gordimer implies in the story? I will argue that the apartheid policies and racial conflict in South Africa were responsible for the self-identification crisis and even the tendency of white South Africans to flee.

\section{Materials and Methods}

In recent years, some of the studies on Nadine Gordimer's works focus on her contribution on fighting against apartheid and how does her works shows a sprits of being a "global citizen" [2]. At the same time, there are other works process to evaluate the value of her literature works and figure out the qualities on them to win the Nobel Prize.

In studies on Gordimer's work, The conservationist, scholars shows a preference on the terrible influence of apartheid on colored people. There are a few works suggested that the policies of apartheid brought negative effects on both white and colored people in South Africa. This study will focus on the plot of the story and the social situation during that period of time, trying to draw a picture of the social identity of white people in South Africa.

\section{Analysis on the distorted white identity in South Africa}

In this section I would analyze the plots in the novel that can reflect the protagonist's white identity and explain the reason for their existence. I will also discuss in sequence about apartheid in South Africa and the social identity of the white people in it, the process of the protagonist seeking identity, the conflict between the culture of the colonist's home country and the traditional Culture of South Africa, and the social problems that make the white people lose the will to live in South Africa.

\subsection{Apartheid in South Africa and identities of white citizens.}

Under apartheid, people were divided into racial groups and kept apart by law. Colored and Indian populations in South Africa were treated unfairly because of their race. Set in the early 1970s, The Conservationist takes a bold approach to apartheid, as the central protagonist is a racist, 
rich, white man. Gordimer characterizes Mehring as an innocent and arrogant man, who expects the world to give him what he wants because of his race. He lives in South Africa but keeps the habits and values of a white European, which cannot be accepted by the black laborers at his farm. Eventually, as a white immigrant, his privileges and conflicts with local tradition expelled any wish of integrating into black-based society.

The social image of white South Africans like Mehring can never be sustainable because of deep prejudices from the beginning. The comparisons throughout the story describe the unequal situation between black and white communities. Griffiths stated that the social image "favored whites in every respect and did not truly reflect South African society at all" [3]. Mehring abuses his status and power by preying on younger girls. In one jarring instance, he spends an entire plane ride touching a teenage girl next to him. She remains quiet until they land when she screams for her mother's help. Throughout the story, Mehring keeps refusing to call the police to deal with a dead body of a nameless black worker. He is not held responsible for his behaviors because of who he is. Gordimer describes the skewed social image of whites in a way that insinuates that apartheid policies created it, which is deeply anachronistic and incoherent.

\subsection{The confounded protagonist and his failure on finding identity.}

Gordimer deploys various motifs of disorientation to dislodge white identity from its self-centeredness. There are parts of the story where time and place, the cornerstones of realism, are forcing Mehring, the protagonist, to reclaim his historical identity more consciously [2]. Mehring once realized that his black laborers do not get enough meat to eat. He then "generously" buys them a single slab of meat for Christmas. As they have nowhere to store the meat, it is stolen by the dog. He watches as the laborers beat the dog to try to get the meat back but doesn't intervene. When they fail, he doesn't buy them a new slab, despite being financially capable. In his mind, he's done more than enough.

After a brief show of kindness, Mehring showed his racist heart out on an airline trip. The contrast with previous farm behaviors also reveals a profound hypocrisy at the heart of the white colonists. Mehring flies back to South Africa from Europe, fully enjoying the advantages of his white identity. He spent the whole trip groping a girl of color sitting next to him. The girl was afraid to tell her family near her because she was afraid of his identity. Like other white men, the protagonist still feels superior to others in a country where he has wealth and privilege. With this ingrained idea and wealth, he was neither accepted nor integrated even when he lived in an all-colored community. Mehring tries to find his place in the community but fails to find one. Most of the white people in his life, however, disagree with his conservative ideas, especially as South Africa is in the midst of a cultural revolution against such racism. Mehring may not succeed, but Gordimer hopes the readers will [2].

\subsection{Conflicts betwween britsh and local culture.}

In order to maintain his cultural identity, Mehring keeps unknowingly violating local traditions and cultures by "emulating the European pastoral tradition of aristocratic civility" [4]. He buys a farm for tax relief and amusement on weekends. Mehring has a flat in a big city, and in truth, his black laborer Jacobus is running the farm and taking care of crops. Children love to follow Jacobus through the gate dancing and laughing. The Africans on the farm inform Jacobus when a new baby is born. Although they received money from Mehring, nobody thinks of him as a relative. Mehring cares nothing about the four-year drought, because he does not depend on the farm. Moreover, Mehring is unlikely to end up being associated with the rural landscape in the way that the 18th-century English gentleman was [4]. In spite of this, he still wants to build a manor in the style of European noble lords, to explore his obsession of living in a land which has thin white roots.

\subsection{Social issues that destoried white people's sense of dwelling}

Different traditions and habits triggered conflicts among different races in South Africa. The crime pandemic also led to conflicts between races. Estimates from Simpson show that overall crime rose by more than 18 percent between 1990 and 1994, compared with 35 percent for violent crime. Most reported crimes are committed in cities, and from the conviction rate (for juveniles) $26 \%$ are believed to be committed by young people. [6]. Approximately 220,000 people were murdered in the past decade: a figure that is four times larger than the total number of deaths of Americans in ten years during the Vietnam War [5].

Gordimer's work shows that that being black in South Africa during post-apartheid meant residing in squalor as well as experiencing high levels of unemployment, racist prejudice, and abuse. On the other hand, being white in South African meant not only wealth and monopoly of resources, but also cross-currents and protests from colored races. Many white South Africans feel so strong a sense of unease they can no longer dwell in the country and try to escape through emigration [3].

Additionally, statistics on the crime rate are generally unreliable. However, we can get a sense of people's anxiety from the horrible effect of the crime. In the story, black workers who have just received wages are immediately murdered in front of convenience stores for the purpose of money, which can also be analyzed in the context of The Times. Especially, the dead body of a black man, which runs through the story, was abandoned in the marshes of Mehring's farm, and no one knows his name. The protagonist himself was indifferent to the murder cases, but that doesn't mean other whites feel the same way. Murder is a good indicator of how violent a society is [7]. In the crime ratio reported by South African 
Police Service (SAPA) in Table 1, South Africa's murder rate remains high in the post-apartheid era. White people may not worry about being murdered, but they also deal with other crimes where racial tensions are irreconcilable, such as Total Sexual Offences, Robbery and Assaults. The crime ratios per 100 thousand of the population reported by SAPS were showed in Table 2 [8]. According to Wakefield \& Tait, the normalization of violence is pervasive in all aspects of South African society. Until recent years, the society continues to be effected by apartheid and poverty. Therefore, we can infer that in the immediate aftermath of apartheid, there was a lack of security for people living in South Africa.

Table ICRIME RATIO PER 100000 OF THE POPULATION IN THE REPUBLIC OF SOUTH AFRICA : APRIL 2004-MARCH 2008

\begin{tabular}{|c|c|c|c|c|}
\hline \multicolumn{5}{|c|}{ Crime Ratio of murder per 100000 of the population } \\
\hline Years & $\mathbf{2 0 0 4 / 2 0 0 5}$ & $\mathbf{2 0 0 5 / 2 0 0 6}$ & $\mathbf{2 0 0 6 / 2 0 0 7}$ & $\mathbf{2 0 0 7 / 2 0 0 8}$ \\
\hline Ratio & $\mathbf{4 0 . 3}$ & $\mathbf{3 9 . 6}$ & $\mathbf{4 0 . 5}$ & $\mathbf{3 8 . 6}$ \\
\hline
\end{tabular}

Table II CRIME RATIO OF MURDER PER 100000 OF THE POPULATION

\begin{tabular}{|c|c|c|c|c|}
\hline \multicolumn{5}{|c|}{$\begin{array}{c}\text { Crime ratio per } 100000 \text { of the population in the RSA: April } \\
\text { 2004-March } 2008\end{array}$} \\
\hline $\begin{array}{c}\text { Crime } \\
\text { Catego } \\
\text { ry }\end{array}$ & $\begin{array}{l}2004 / 20 \\
05\end{array}$ & $2005 / 2006$ & $\begin{array}{l}2006 / 200 \\
7\end{array}$ & $2007 / 2008$ \\
\hline Murder & 40.3 & 39.6 & 40.5 & 38.6 \\
\hline $\begin{array}{c}\text { Total } \\
\text { Sexual } \\
\text { Offenc } \\
\text { es }\end{array}$ & 148.4 & 145.2 & 137.6 & 133.4 \\
\hline $\begin{array}{l}\text { Attemp } \\
\text { ted } \\
\text { murder }\end{array}$ & 52.6 & 43.8 & 42.5 & 39.3 \\
\hline $\begin{array}{c}\text { Assault } \\
\text { with } \\
\text { the } \\
\text { intent } \\
\text { to } \\
\text { inflict } \\
\text { grievo } \\
\text { us } \\
\text { bodily } \\
\text { harm }\end{array}$ & 535.3 & 484.0 & 460.1 & 439.1 \\
\hline $\begin{array}{c}\text { Comm } \\
\text { on } \\
\text { assault }\end{array}$ & 575.0 & 485.3 & 443.2 & 413.9 \\
\hline $\begin{array}{l}\text { Robber } \\
\text { y with } \\
\text { aggrav } \\
\text { ating } \\
\text { circum } \\
\text { stances }\end{array}$ & 272.2 & 255.3 & 267.1 & 247.3 \\
\hline $\begin{array}{c}\text { Comm } \\
\text { on } \\
\text { robber } \\
y\end{array}$ & 195.0 & 159.4 & 150.1 & 135.8 \\
\hline $\begin{array}{c}\text { CONT } \\
\text { ACT } \\
\text { CRIM } \\
\text { ES } \\
\end{array}$ & $1,818.7$ & $1,612.6$ & $1,541.1$ & $1,447.3$ \\
\hline
\end{tabular}

At the end of the story, a huge flood ruins the farm. Mehring cannot get to the farm, so he leaves his black servant Jacobus in charge. The floodwaters are so intense that they bring the dead body back to the surface. Jacobus decides that the man deserves a proper burial this time around, and the farm workers finally lay him to rest. During this time, Mehring's white wife, mistress and son are all fleeing South Africa. This represents the slow but inevitable and inexorable progression toward the loss of white minority rule and the collapse of apartheid. White immigrants tried so hard to find a space in South Africa, but they failed because they ignored the benefits of colored groups when they created apartheid. The failure in the search for a white social image in the country mirrors the national failure of apartheid in South Africa.

\section{Discussion}

The objective of this research is to figure out how did the story of The conservationist illustrate the social picture of white South Africans and how did their willingness of staying be distorted by social issues. I have provided discussions on plots in The conservationist and its approach to reflect the damages on both colored and white people, the skewed social images of white people, the social problems caused by the conflicts within races. It is of great significance for us to understand and reflect on apartheid in South Africa. However, Nadine Gordimer's white character failed to integrate into the colored society in both story and reality. There is always a glimmer of hope that people in current society can abandon their arrogance and discrimination and find common ground between different cultures in order to build a more harmonious domestic or international community than we have today.

There are several limitations on this method. Gordimer's work was highly political, and she used it to call for a revolution in rights for people of color. This kind of social revolution and the change of social system are also important factors affecting the social status of white people. Since the story rarely depicts the struggle of the colored people, the researchers would have missed this point if they had only analyzed the plot. Also, a turbulent social environment and high crime rates often increase stress, and anyone living in the area may develop mental problems and wish to escape. The grotesque, twisted spiritual world and living conditions of the white protagonists in this work deserve detailed analysis. Finally, The social relations of white people in South Africa are also worth discussing. For example, Mehring's ex-wife, son and girlfriend all emigrated from South Africa. Will it affect him? Can this separation of family or personal relationships also account for the mass exodus of white people?

The problems and contradictions left by colonialism are still evident in the 21 st century. For example, the European refugee wave, in which a large number of European refugees fled to seek asylum in Europe, changed the formerly stable composition of the white society. Society badly needs to integrate mutually acceptable systems to avoid another identity crisis. At the same time, we still lack concrete methodology. Further 
studies are demanded to explore the meaning and approaches of cultural and racial fusion.

\section{Conclusion}

It has been determined that the social identity of white South Africans is a disaster for every ethnic group in the country. It may have been feasible at the beginning, when advocated by colonists. As time goes by, the ongoing conflicts between colored and white South Africans make the society divisive and turbulent. Most isolated black residents commit crimes for living, and some of them revolt for independence. White people cannot be at peace. They may escape from cities to a farm like Mehring, but that does not help. White people's hearts left a yearning for the culture that brought by their ancestors, has not been able to integrate into the local communities of color. Even if some whites identify with the country, they will never be able to bear the pain of not being accepted by the majority. In short, Gordimer's writing displays grace, power and matchless coherence. She hopes the sad ending of Mehring would remind the Africans to reach for a new and sustainable social identity.

\section{REFERENCES}

1. Bhabha, Homi. "The World and the Home." Social Text, no. 31/32, 1992, pp. 141-153. JSTOR, www.jstor.org/stable/466222. Accessed 22 Oct 2019.

2. Coundouriotis, Eleni. "Rethinking Cosmopolitanism in Nadine Gordimer's The Conservationist." College Literature, vol. 33, no. 3, 2006, pp. 1-28. JSTOR, www.jstor.org/stable/25115364. Accessed 14 Oct 2019.

3. Griffiths, Dominic, and Maria L. C. Prozesky. "The Politics of Dwelling: Being White / Being South African." Africa Today, vol. 56, no. 4, 2010, pp. 2241.

JSTOR, www.jstor.org/stable/10.2979/aft.2010.56.4.22. Accessed 14 Oct 2019.

4. Rich, Paul. "Tradition and Revolt in South African Fiction: The Novels of Andre Brink, Nadine Gordimer and J. M. Coetzee." Journal of Southern African Studies, vol. 9, no. 1, 1982, pp. 54-73. JSTOR, www.jstor.org/stable/2636732. Accessed 13 Oct 2019.

5. Breetzke, G.D. "Understanding The Magnitude And Extent Of Crime In Post-Apartheid South Africa". Social Identities, vol 18, no. 3, 2012, pp. 299-315.

6. Simpson, G. (1998). Urban crime and violence in South Africa. In C. Petty \& M. Brown (Eds.), Justice for children: Challenges for policy and practice in sub-Saharan Africa (pp. 6671). London: Save the Children.

7. Wakefield, L., \& Tait, S. (2015). Crime and Violence in Formal and Informal Urban Spaces in South Africa Citizen Security Dialogues Dispatches from South Africa: Foreword. Stability: International Journal of Security and Development, 4(1), Art. 26.
8. South African Police Service. (2014) RSA: April to March 2004 - 2014: Provincial and National Figures and Ratios. https://www.saps.gov.za/resource_centre/publication s/statistics/crimestats/2014/crime_stats.php 